\title{
Nation-Building and Conflict in Modern Africa
}

Sanghamitra Bandyopadhyay ${ }^{*}$ and Elliott Green ${ }^{\dagger}$

Department of Economics and STICERD, LSE and

Department of International Development, LSE

The Suntory Centre

Suntory and Toyota International Centres for Economics and Related Disciplines

London School of Economics and Political Science Houghton Street

London WC2A 2AE

Tel: (020) 79556674
EOPP/2008/26

\footnotetext{
*email s.bandyopadhyay@lse.ac.uk

† email e.d.green@lse.ac.uk
} 


\begin{abstract}
Nation-building has long been seen as an important focus for postcolonial African governments. However, up until now there has been no empirical analysis of either the origins or consequences of these policies. Here we compile an original dataset measuring nine different types of nation-building policies. Using Ordinary Least Squares regressions, we first show that nation-building policies are correlated with larger states and British colonialism. We then use logistic regressions to test the effect of such policies on civil wars using two different datasets of civil wars, and find no evidence that such policies have helped to prevent civil war.
\end{abstract}

Keywords: conflict, nation building, Africa, Sub-Saharan Africa 
This series is published by the Economic Organisation and Public Policy Programme (EOPP) located within the Suntory and Toyota International Centres for Economics and Related Disciplines (STICERD) at the London School of Economics and Political Science. This new series is an amalgamation of the Development Economics Discussion Papers and the Political Economy and Public Policy Discussion Papers. The programme was established in October 1998 as a successor to the Development Economics Research Programme. The work of the programme is mainly in the fields of development economics, public economics and political economy. It is directed by Maitreesh Ghatak. Oriana Bandiera, Robin Burgess, and Andrea Prat serve as codirectors, and associated faculty consist of Timothy Besley, Jean-Paul Faguet, Henrik Kleven, Valentino Larcinese, Gerard Padro i Miquel, Torsten Persson, Nicholas Stern, and Daniel M. Sturm. Further details about the programme and its work can be viewed on our web site at http://sticerd.lse.ac.uk/research/eopp.

Our Discussion Paper series is available to download at:

http://sticerd.lse.ac.uk/_new/publications/series.asp?prog=EOPP

For any other information relating to this series please contact Leila Alberici on:

Telephone: UK+20 79556674

Fax: $\quad$ UK+20 $\quad$ : $\quad$ (a556951

Email: $\quad$ l.alberici @lse.ac.uk

(C) The authors. All rights reserved. Short sections of text, not to exceed two paragraphs, may be quoted without explicit permission provided that full credit, including (C) notice, is given to the source. 


\section{Introduction}

Upon African decolonization in the 1950s and 1960s social scientists were concerned about the need for what was then called "national integration" in societies with multiple ethnic, religious and racial cleavages (Binder, 1964; Coleman \& Rosberg, 1966; Zolberg, 1967). This concern has been more recently resurrected by Collier (2009), Miguel (2004) and others who have argued for nation-building as a policy to promote state building in a continent now notorious for political instability. It is especially important to assess nation-building policies in light of calls for "nation building [to] move onto government policy agendas, especially in Africa" (Miguel, 2004, p. 362).

However, heretofore no one has examined the effects of nation-building on national integration in post-colonial Africa. Miguel (2004), for instance, shows that ethnic diversity does not have an effect on public goods provision in a test site in Tanzania while it does in a similar site in Kenya, but can only speculate as to the mechanisms behind these difference. Similarly, Collier (2009, p. 68) argues for nation-building policies while also noting that it is "intrinsically difficult to approach scientifically" whether nation-building has successful. Finally, Kevane (2005) shows some relationship between national imagery on postage stamps and subsequent conflict but his results are not unequivocal and he does not expand his analysis to other types of nation-building policies. ${ }^{1}$

Thus for the first time we examine here nine different types of nation-building policies in postcolonial Africa. These policies range from the more banal - such as changing the name of the state, capital, national anthem or currency - to more profound changes such as the declaration of a oneparty state, the nationalization of land and the introduction of obligatory military conscription or national service. We use Ordinary Least Squares to first show that state size and British colonialism are correlated with higher numbers of nation-building policies per country, thereby adding to previous literature from Herbst (2000) and others on the problems of the extension of state power across large territories in the African context. We then investigate whether these policies have any correlation with civil war onset under the assumption that we should find that a negative and significant relationship between nation-building and political instability. However, using logistic regressions we find that none of these variables are ever negatively and significantly associated with the onset of civil war, and that across many specifications there is in fact a positive and significant relationship between nation-building policies and civil wars. In other words, we find no evidence that nation-building policies have prevented civil war in post-colonial Africa despite numerous efforts at nation-building across a wide variety of states.

The paper is organized as follows. In Section 2 we examine the nine nation-building policies in detail. In Section 3 we present our empirical results. In Section 4 we discuss and interpret our findings, and in Section 5 we conclude.

\footnotetext{
${ }^{1}$ More specifically, Kevane (2005) finds that nation-oriented stamps (i.e., those focussed on development or with multi-ethnic or national imagery) are sometimes correlated with lower subsequent levels of conflict but this result depends on the type of conflict analyzed and the specific control variables added to the regression.
} 


\section{Nation Building Policies}

National integration was one of the most prominent topics among both academics and policymakers in Africa upon independence in the 1960s. Indeed, one scholar noted at the time that nationbuilding "takes precedence over all other tasks, including economic development" (Zolberg, 1967, p. 461). Yet heretofore there has not been any comprehensive database of nation-building policies in post-colonial Africa, let alone one that attempts to understand its causes and consequences. ${ }^{2}$ As such we consider nine different types of nation-building policies here, all of which have been implemented in at least eight instances. While at first some might appear banal in their effects on national integration, such as changing the name of the state, capital city or currency, scholars like Billig (1995) have long considered their effects on nation formation merely to be subtle rather than unimportant. In the African context, Young (2004) previously noted how "innumerable rituals of state drummed the national idea into the public consciousness: national holidays, national anthems, daily flag-raising ceremonies at all administrative headquarters. In a dozen banal ways, the nation was subliminally communicated through its ubiquitous flag, its currency, its postage stamps, its identity cards." However, our goal here is to examine variation in nation-building policies across Africa, and, inasmuch as all countries adopted new flags and anthems upon independence, we do not include flags or national anthems in our analysis. ${ }^{3}$ We thus start with more banal aspects of nation-building before moving to more overt and profound policies such as the creation of one-party states and non-ethnic censuses.

\subsection{Changing State Names}

Governments of newly-created states have often sought to name or rename their state in order to give it political and historical legitimacy amongst its citizenry. Outside Africa the new government of the Gilbert islands changed its name to Kiribati upon independence in 1979 to reflect the local pronounciation of "Gilberts," while the governments of Ceylon and Burma changed their countries' names to Sri Lanka and Myanmar in 1972 and 1989, respectively, in order to replace former colonial state names with indigneous ones. In Africa governments have changed state names largely for two related reasons. First, several governments renamed countries whose names derived from extant indigenous ethnic groups and were thus seen by post-colonial rulers as divisive. For instance, Dahomey drew

\footnotetext{
${ }^{2}$ Even more qualitative efforts at analyzing nation-building policies in Africa, such as Kevane (2008), have failed to trace any line of causality from nation-building to political outcomes.

${ }^{3}$ Some countries continued to change their flags and anthems after independence, but these changes were more linked to regime changes rather than efforts at nation-building. Moreover, many post-independence flag and anthem changes are already captured by other contemporaneous nation-building policies below, such as in Burkina Faso in 1984 (land nationalization and state name change), the DRC in 1971 and 1997 (state name change), and Ethiopia in 1975 (land nationalization and the abolition of the monarchy). Nonetheless, our results are robust to the inclusion of data on post-independence flag and anthem changes.
} 
its name from a local pre-colonial kingdom in the southern part of the country, leading President Mathieu Kérékou's government to rename the country Benin in 1975 after the Bight of Benin. The Democratic Republic of Congo was similarly named after an indigenous ethnic group, the Kongo; thus President Mobutu renamed the country Zaire in 1971 after the Portuguese corruption of the Kongo word "nzadi," meaning "large river."

A second strategy was adopted by countries with names more directly associated with natural features or colonial history; in these cases governments carefully chose more indigenous African state names which could appeal to the pre-colonial past but which had no contemporary ethnic relevance. For instance, Kwame Nkrumah's government changed the name of the Gold Coast to Ghana upon independence despite the fact that the ancient Kingdom of Ghana - which had reached its height in the early 11th century - had in fact been located in present-day Mali and Mauritania. Robert Mugabe's government also used the pre-colonial past, namely the Great Zimbabwe medieval ruins, to rename Rhodesia upon independence in 1980. In Nyasaland, which the British had named after Lake Nyasa, President Hastings Banda renamed the country Malawi after a pre-colonial ethnic group known as the Maravi. Finally, in Upper Volta, which took its name from the Volta river, President Thomas Sankara renamed the country "Burkina Faso" in 1984, meaning "land of the upright" in the local Mossi and Dioula languages.

\subsection{Changing Capital Cities' Names and Locations}

Numerous governments have changed the location of their capital city from coastal cities to inland sites more centrally located in order to make their governments more accessible to and representative of its entire citizenry. Outside Africa the newly-independent governments of both Australia and the United States created new capital cities in geographically central locations, while in Brazil the capital was changed more than a century after independence from Rio de Janeiro to the more centrallylocated and specially-built Brasilia in 1960. In Africa President Nyerere relocated the capital of Tanzania from the coast city of Dar es Salaam to more centrally-located Dodoma in 1973, an act that "clearly demonstrated his larger purpose of moving beyond inherited localized identities" (Collier, 2009, p. 67). In neighbouring Malawi President Banda also relocated the capital from the southern city of Zomba to the centrally-located Lilongwe in 1965, while in Nigeria the Gowon government moved the capital from coastal Lagos to the planned and centrally-located city of Abuja in 1976.

Other governments did not move their capital cities but renamed them instead, especially in cases where their former names were associated with colonial history. Outside Africa this rationale has led to numerous name changes of major cities in India (Bangalore to Bengaluru, Calcutta to Kolkata and Cochin to Kochi) and Pakistan (Campbellpur to Attock, Fort Sandeman to Zhob), among others. In Africa many governments have implemented similar name changes: for instance, in 1973 President Tombalbaye of Chad renamed the capital city from Fort-Lamy, named after a French army officer, to N'Djamena, meaning "place of rest in Arabic." Upon independence in 1975 the Mozambiquean 
government renamed its capital city from Lourenço Marques, named after a 16th-century Portuguese explorer, to Maputo, which took its name from a local river. Finally, in the DRC President Mobutu not only changed the capital name from Leopoldville to Kinshasa but also changed the name of other major cities like Albertville (to Kalemie), Elizabethville (Lubumbashi), Luluabourg (Kananga) and Stanleyville (Kisangani).

\subsection{Changing National Currencies}

Helleiner (1998), among others, has argued that national currencies can contribute to nation-building in a variety of ways, both through the imagery present on notes and coins but also through the stable management of currency that can help to provide for stable governance. In Africa most countries inherited colonial names for their currencies, including the Franc, Pound and Escudo in Francophone, Anglophone and Lusophone Africa, respectively. As a result many post-colonial governments changed the name of their currencies as a symbolic gesture after independence. For instance, Kwame Nkrumah's government replaced the Ghanian Pound with the Cedi in 1965, named after a local Akan word for a cowry shell, while in both Malawi (1968) and Zambia (1971) the pound was replaced by the Kwacha, which means "dawn" in both the Bemba and Njanja languages. Similarly, in Sierra Leone the new currency became the Leone, after the name of the country, while in Angola the Escudo was replaced by the Kwanza, the name of a local river.

In Francophone Africa a majority of former French colonies continued to use the CFA franc after independence. However, both of the former French colonies countries which had never been part of the CFA franc zone changed their currencies, with the Madagascar government adopting the Ariary (the name of a pre-colonial currency) in 1961 and the Mauritanian government introducing the Ouguiya (a local Arabic dialect word for "ounce") in 1973. Finally, countries in southern Africa which had formerly used the South African Rand created new national currencies as well, with Swaziland introducing the Lilangeni ("money" in Swati) in 1974 and Botswana adopting the Pula ("blessing" or "river" in Setswana) in 1976.

\subsection{Conscription and National Service}

The importance of military conscription for nation formation has long been noted by scholars of nationalism. For instance, in Russia the introduction of conscription in 1874 drew from the idea that "obligatory participation in military service... presents the best means for the weakening of tribal differences among the people" (Sanborn, 2002, p. 12), while in Weber (1976)'s classic study one of the mechanisms that turned "peasants into Frenchmen" in the late 19th century was military service. In Africa many countries have similarly promoted obligatory military conscription and/or national service for secondary school or university students as a means to integrate their citizens. In Côte d'Ivoire, for instance, all Ivoirian male citizens over the age of 21 have been required to serve 6 
months in the military since 1961; more recently in Sudan the National Service Act of 1992 mandated 2 years of national service from all citizens, but with a reduced load of 18 months and 12 months for high school and university graduates, respectively. Similarly, Eritrea introduced conscription after its independence in 1994, whereby all citizens of both sexes must perform eighteen months of military service due to the government's claimed need to "foster national unity among our people by eliminating sub-national feelings" (Kibreab, 2009, p. 44).

Other governments have instead promoted non-military national service. For instance, Hailie Selassie's government created the Ethiopian University Service in 1964, which mandated a year's break of schooling for all university students between their third and fourth years to serve in a rural area for one year. The Guinean government started a political education course in 1961 for secondary school students; by 1971 students were instead sent to join the national popular militia whose explicit purpose was to "guard national frontiers" and "patrol public morality" (Harber, 1989, pp. 145, 154). The Zambian National Service, which previously only drew primary school graduates, was redesigned in 1975 to enrol all university students for twenty months alongside teachers and party leaders for shorter periods of time. Finally, in Nigeria all university students were required from 1973 to join the National Youth Service Corps, which was designed to promote national unity by posting students for one year to a state other than their own.

\subsection{Religious and Linguistic Homogenization}

Nation-building has historically meant religious and linguistic homogenization, to the point where many scholars such as Laitin (2007) hold language-speaking communities and nations to be largely synonymous. In Africa several governments have attempted to promote a national or state religion, for instance in the declaration of Islam as the state religion in Mauritania (1985) and Comoros (2001) and the incorporation of Sharia law into the Sudanese legal code in 1983. While most African states have continued to use their former colonial language as their main lingua franca, in a small number of cases African regimes have promoted a new lingua franca. Most famous in this regard was President Nyerere's declaration of Swahili as Tanzania's national language in 1967, which involved promoting its use in government, schools and in the media, while Nyerere also personally translated several of Shakespeare's plays into Swahili. Similarly, upon independence Somalia was divided by the two former colonial languages of English and Italian alongside ten different writing scripts for Somali; as a result Siad Barre's government passed a law in 1972 declaring Somali and a standardized Romanized script as the new sole official language.

However, perhaps the best example of a regime that promoted religious and linguistic homogenization was Haile Selassie's Ethiopia, where Amharic became the sole language of primary education in 1943 and literature was banned in all other languages. In a particularly clever move Selassie also required missionaries to use Amharic: since they were already predominately located among non-Amharic speaker they thus became the "workhorses of Selassie's national integration project" 
(Smith, 2008, p. 218). Selassie also severed the link between the Ethiopian and Coptic (Egyptian) Orthodox Churches, thereby turning the Ethiopian church into a national church for the first time; as such the first ever native Ethiopian Abune (Archbishop) was appointed in 1951 and promoted to Patriarch in 1959. Moreover, the 1955 constitution declared the church to be the national church and for the first time legally required the Emperor to be a member of the church. The penal code of 1957 established official religious holidays, all of which were Orthodox festivals, while the constitution required the Emperor to be named in all religious services. Although public office was not denied to non-Christians - by the late 1960s $13 \%$ of the members of the Chamber of Deputies were Muslim (Markakis \& Beyene, 1967, p. 212) - many non-Amharic and non-Christian Ethiopians thus converted to Christianity and/or changed their names to Amharic ones as a result of these policies.

\subsection{Republican and Centralization Policies}

Many post-independence African leaders saw the maintenance of local ethnic identities as an impediment to the construction of new national identities: President Samora Machel of Mozambique, for instance, famously declared that, "for the nation to live, the tribe must die" (Mamdani, 1996, p. 135). Thus many leaders attempted to abolish traditional kingdoms and federal systems that retrenched ethnic identities. In the former case several independent African states inherited a monarchical head of state who had historically ruled on behalf of only some of the citizenry and who was thus a potentially divisive figure. In Central Africa both Burundi and Uganda became independent with a traditional king as their head of state, only to see subsequent governments abolish both monarchies in 1966 and 1967, respectively. In Ethiopia the Emperor was seen as biased towards the Amharic ethnic group, and thus the Derg which took power in 1975 also abolished the monarchy as one of its first acts.

Federalism has also been seen by various regimes as an impediment to the construction of a unified national identity. For instance, after the United Nations promoted the creation of the Federation of Ethiopia and Eritrea in 1950, Hailie Selassie dissolved the union and re-centralized Ethiopia in 1962; in neighbouring Sudan President Nimerei's government similarly abolished the Southern Regional government in 1983 that had been formed as part of the 1972 Addis Ababa peace agreement. In the DRC President Mobutu abolished the federal system in 1965 as one of his first acts of office, while President Johnson Aguiyi-Ironsi abolished federalism in Nigeria during his brief tenure in office in 1966. Finally, in Cameroon, which became independent in 1961 with separate federal states for English-speaking West Cameroon and French-speaking East Cameroon, President Ahidjou declared a unitary state in 1972 and changed the official name of the country from the Federal Republic of Cameroon to the United Republic of Cameroon. 


\subsection{One-Party States}

Historically political parties were seen by both governments and political thinkers like Hume and Rousseau as factional and not conducive to nation-building (Przeworski, 2009). More recently many leaders across Africa banned opposition parties in (what they claimed) were efforts to reduce political factionalism and unite their countries by both banning ethnic-based associations and creating a single political organization open to all citizens. As such many former French colonies such as Guinea (1958), Mali (1960), Niger (1960) and Upper Volta (1960) became one-party states immediately upon independence. In several states the creation of a one-party system allowed leaders more space to pursue nation-building policies: for instance, in the DRC President Mobutu banned political party activities upon taking office in 1965, outlawed ethnic associations in 1968 and promulgated an official ideology of authenticité in 1971 (Young, 1976, p. 211). President Ahidjo's government similarly declared a one-party state in East Cameroon in 1962 and in West Cameroon in 1966, and subsequently outlawed "any associations exhibiting an exclusively tribal or clan character" (Bayart, 1973, p. 128).

One-party states were not, however, limited to French-speaking Africa. Most notable among the Anglophone countries was Kwame Nkrumah and his Convention People's Party (CPP) in Ghana; after declaring famously that "Ghana is the CPP and the CPP is Ghana," Nkrumah created a oneparty state in 1964 (followed by a perfunctory referendum with 99.9\% support). Kenneth Kaunda declared Zambia a one-party state in 1972 partially in response to the creation of political opposition parties along ethnic lines, namely the African National Congress (dominated by Ila and Tonga) and the United Progressive Party (dominated by Bemba) (Marten \& Kula, 2008, p. 306). More recently President Museveni of Uganda promoted a "no-party" system of government upon taking office in 1986, whereby candidates could not be sponsored by political parties due to the concern that political parties had previously divided citizens along both religious and ethnic lines. However, despite a referendum which found majority support for a continuation of "no-party" rule in 2000, a second referendum was held in 2005 which instead produced support for a return to multi-party politics, and in 2006 Uganda held its first multi-party election since 1980.

\subsection{Non-Ethnic Censuses}

Various government have used their censuses as tools of nation-building, not only in Africa: Anderson (1991) has argued that censuses in south-east Asia helped to create nations through enumerating citizens and thereby including them in the national "imagined community." More recently Lieberman \& Singh (2009) have similarly noted how the institutionalization of ethnicity through censuses can be linked to the subsequent outbreak of political violence. In Africa there has been a conscious decision in such states as Ghana, Malawi and Tanzania to not collect census data along ethnic lines from the late 1960s; in Ghana the Acheampong government also banned the word "tribe" from official government usage in 1972 "as a step to eliminate divisive and tribal forces which militate against 
national unity and progress" (Chazan, 1982, p. 464). In the Central African Republic national governments failed to collect data on ethnicity in the 1961 and 1975 censuses, fitting in with the emphasis on citizens' common Bantu origins expressed in the opening line of its national anthem, 'Ô Centrafrique, ô berceau des Bantous!' (Oh Central Africa, cradle of the Bantu!).

Thus by 2000 only $44 \%$ of African countries asked questions about ethnicity on their census, compared to $65 \%$ in Asia and $83 \%$ in North and South America (Morning, 2008, p. 246). Indeed, countries like Rwanda, which had previously always asked questions about ethnicity in census questionnaires, declined to do so for its first post-genocide census in 2002. Similarly, the Khartoum government refused, against the wishes of the Government of Southern Sudan, to ask questions about ethnicity or religion in the Sudanese census of 2008 (Santschi, 2008, p. 635).

\subsection{Land Nationalization}

Concerns that land is held unequally and that such inequality has potential to disrupt nation-building policies has been a common reason given by various modern governments interested in land reform policies. In China, for instance, Sun-Yat Sen's interest in land reform was part and parcel of his early nationalist policies (Schiffrin, 1957), while post-colonial land reform policies in such countries as Burma, Singapore and South Korea were designed both to alleviate political tensions and to promote economic growth. In Africa colonial rulers designated land laws according to what they saw as "customary" law, whereby each ethnic group had its own "tribal" chief who controlled the group's land. As such African states reached independence with land rights tied to ethnic identity, leading many subsequent regimes to promote land nationalization in order to depoliticize ethnicity, harmonize and simplify the legal code and promote the mobility of citizens. Indeed, in Ghana one major impetus behind nationalization in 1962 was Nkrumah's worry that land revenue in the South had been used to support the pro-federalism and overwhelmingly Ashanti-based National Liberation Movement (Kasanga \& Kotey, 2001, p. 2). In a similar fashion Tanzania and Sudan land nationalization in 1963 and 1970, respectively, went hand-in-hand with the wholesale abolition of traditional leaders. In Nigeria land policy prior to nationalization was a legacy of its dual colonial heritage, with land in northern Nigeria governed by the state while in the south it remained under customary tenure; the 1978 Land Use Decree, however, created a single system of land tenure, with subsequent opposition from the traditional rulers whose land rights had been abolished (Francis, 1984, pp. 6, 11). More recently in Eritrea the government nationalized all land in 1994, with an explicit emphasis on encouraging mobility between regions and making land available to all citizens of either sex above the age of 18 "without any discrimination of sex, religion, tribalism and side" (Tronvoll, 1998, p. 472). 


\subsection{Other Nation-Building Policies}

These nine different types of nation-building policies do not capture the full range of policies implemented by various nationalist African governments. For instance, many governments focussed their education policies on promoting nation-building. Thus in Kenya a 1975 curriculum guide noted that "education in Kenya must foster a sense of nationhood and promote national unity," while a secondary school history syllabus asked students to "demonstrate patriotism and national pride" (Harber, 1989, pp. 40, 52). Similarly, in Nigeria President Yakubu Gowon's government required pupils to recite the national pledge at the beginning and end of each day, while in Zambia secondary schools were "to impart and instil in the pupils a knowledge of and a pride in Zambia's heritage" (Harber, 1989, p. 193). Finally, in Mozambique schools were exhorted by President Samora Machel to "be centres for the propagation of national culture" and "affirm and develop our Mozambican personality by strengthening our unity" (Barnes, 1982, p. 172); in particular Machel's government promoted a new nationalist "People's History" through efforts to not only collect local histories but emphasize their national commonalities (Gray, 1982).

Other policies were more outlandish. As with state, capital and currency names, several presidents changed their names to more African-sounding ones: President Étienne Eyadéma of Togo changed his first name to Gnansingbe in 1974 while President Francisco Macías Nguema of Equatorial Guinea changed his name to Masie Nguema Biyogo Negue Ndong in $1976 .{ }^{4}$ In Zaire President Mobutu created the abacost national dress - from the French à bas le costume (down with suits) - which he then mandated as the national business suit for men while banning western dresses and skirts for women in favour of the pagne (traditional long dress). Kenneth Kaunda similarly declared nshima (maize meal) the national food and the chitenge skirt the national dress in Zambia, despite the fact that both had been introduced by European settlers (Chan, 1992, p. 23). Other leaders such as Hastings Banda in Malawi and Juvenal Habyarimana in Rwanda promoted nationalist dances celebrating the anti-colonial struggle; in Mobutu's Zaire such dance performances were officially described as "the national consecration of our vital force and our arrival at the national spirit" (Dunn, 2001, p. 242).

In all of these cases, however, the policies are more difficult to quantify than the policies discussed above. In some cases the total number of policies is very small: for instance, only seven African Presidents changed their names while in office, among whom two did so due to their conversion to Islam. ${ }^{5}$ Finally, in almost all of these cases these additional policies coincided with policies which we have already listed above, which suggests that we have already coded their effects quantitatively.

\footnotetext{
${ }^{4}$ Perhaps most infamously, President Joseph Desiré Mobutu of Zaire changed his name to Mobutu Sese Seko Kuku Ngbedu Waza Banga in 1972, which meant "the all-powerful warrior who, because of his endurance and inflexible will to win, goes from conquest to conquest, leaving fire in his wake."

${ }^{5}$ Namely Omar Bongo Ondimba (formerly Albert-Bernard Bongo) of Gabon in 1973 and Salah Eddine Ahmed Bokassa (Jean-Bédel Bokassa) of the short-lived Central African Empire in 1976. Bokassa's conversion was shortlived, however, and he reverted to his former name later in the same year.
} 


\section{Empirical Analysis}

\subsection{The dataset}

In this section, we describe the dataset and the variables that have been constructed for empirical analysis of both the determinants of nation building policies and the relationship between the onset of civil wars and nation building policies. For the first relationship the dependent variable is the cumulative number of nation-building policies per country over the entire time period represented in the dataset (1940 or the year of independence to 1997). For the second relationship the dependent variable is onset of civil war, which is a binary variable which we measure in two ways. First, we use the variable onset of civil war as avaialble in the Fearon and Laitin (2003) dataset, from 1945 to 1997. The variable takes value $=1$ if there is onset of civil war in a given year, and value $=0$ if there is no civil war. We also use the civil war onset variable from Miguel et al. (2004), originally taken from a Peace Research Institute of Oslo (PRIO) dataset and covering the years 1981-1999. We also use several control variables in the estimation of our models, which we detail in Sections 3.2 and 3.3 below.

Our main independent variables, the nation building policies described in Section 2, are measured in two ways. They are first considered as binary variables whereby they take value $=1$ if a particular nation building policy is undertaken in a given year, and value $=0$ otherwise. We also introduce a second set of definitions for one-party states, land nationalization and conscription, where the variable takes the value $=1$ for all years for which the policy was implemented and not just in the year of implementation to account for the fact that the effects of these policies are spread throughout the period in which they are in place. To distinguish these two sets of nation-building variables we identify them with a 1 or 2 suffix (as in one-party 1 and one-party 2).

The summary statistics of each of these nation building policies are summarised in Table 1 below. There are 45 countries in our dataset, listed in Appendix B in Table 5.

\subsection{Explaining Nation-Building Policies}

One striking fact about these different types of nation-building policies is the variation in their implementation across Africa. Thus, while some countries like Guinea-Bissau, Rwanda and Togo implemented only one policy each since independence, both Nigeria and Uganda implemented nine distinct nation-building policies since indepencence. Strong variation even exists between the two African countries not to experience European colonization, with Liberia never having implemented any nation-building policies while Ethiopia implemented seven since 1940.

There are several potential reasons for this variation. First, as noted above ethnic diversity has long been seen as an impediment that nation-building could help overcome; thus we should expect to see a positive correlation between ethnic diversity at independence and subsequent nation-building policies. Second, Herbst (2000) has argued that African states have historically had difficulties 


\begin{tabular}{lrrr}
\hline \hline Variable & Obs & Mean & Std. Dev. \\
\hline collected & 1593 & 0.1080 & 0.3486 \\
state name & 1593 & 0.0069 & 0.0828 \\
capital name or location & 1593 & 0.0063 & 0.0790 \\
currency & 1593 & 0.0100 & 0.0997 \\
centralization & 1593 & 0.0056 & 0.0750 \\
religion or language & 1593 & 0.0038 & 0.0613 \\
non-ethnic census & 1593 & 0.0232 & 0.1507 \\
one party 1 & 1593 & 0.0289 & 0.1675 \\
land nationalization 1 & 1593 & 0.0094 & 0.0966 \\
conscription 1 & 1593 & 0.0138 & 0.1167 \\
one party 2 & 1663 & 0.6055 & 0.4889 \\
land nationalization 2 & 1681 & 0.2641 & 0.4410 \\
conscription 2 & 1721 & 0.3457 & 0.4757 \\
\hline \hline
\end{tabular}

Table 1: Descriptive Statistics of Nation Building Policy Variables

extending their power across space, whether in the pre-colonial, colonial or post-colonial periods. Larger states would thus potentially need more nation-building policies to achieve their goal of national integration, which would lead us to expect state size to be positively correlated with nationbuilding policies. Third, ceteris paribus we would expect states with greater capacity to implement more nation-building policies. Indeed, Gennaioli and Rainer (2007) find that African states with higher proportions of ethnic groups with a pre-colonial history of centralized government have better post-colonial public goods provisions. Along these lines we might thus expect a similar positive relationship between pre-colonial centralization and post-colonial nation-building as well. Fourth, inasmuch as states at higher levels of development might not need to implement as many nationbuilding policies due to the political stability provided by higher incomes, we would expect to see a negative relationship between GDP/capita at independence and subsequent nation-building policies. Fifth and finally, we would also expect to see variation according to the identity of the colonial power, especially considering previous research which finds post-colonial differences in political and economic development between former British and French colonies within Africa (Blanton et al., 2001; Grier, 1999). We would especially expect to find this difference in nation-building policies since French colonies tended to stay within the CFA zone and thus did not create their own currencies (with the two exceptions noted above).

To test these relationships we therefore regress the log of total number of nation-building policies per country on a series of variables, namely state size as measured by log of kilometres squared and $\log$ of population in 1960, ethno-linguisitic fractionalization in $1961,{ }^{6}$ pre-colonial centralization,

\footnotetext{
${ }^{6}$ The data source, Roeder (2001), coded ethnicity based on Soviet data from the 1960s. It has been criticized
} 
GDP/capita in 1960, log of the number of years since independence and dummies for British and Portuguese colonization, and use OLS to estimate the model. ${ }^{7}$ The model we estimate is given by:

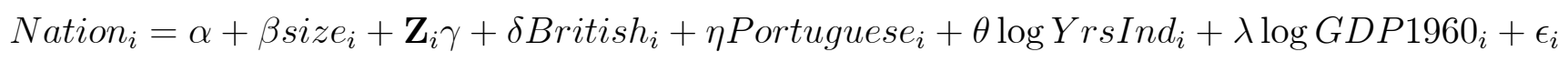

where, Nation $_{i}$ is measured the log of the number of nation building policies implemented by country $i$ and size $_{i}$ is the size of the state, measured as either log kilometre squared area of the country or $\log$ of population of the country in 1960. The vector $\mathbf{Z}_{i}$ consists of two explanatory variables, namely pre-colonial centralisation or ethnoliguistic fractionalization index; we test for the effect of pre-colonial centralization and ethno-linguistic fractionalization separately inasmuch as Gennaioli and Rainer (2007) find the two to be significantly correlated. British B $_{i}$ and Portuguese Pre dummy are variables which take the value $=1$ if the country $i$ was a British or Portuguese colony, respectively, and $=0$ otherwise. $\log Y r s I n d_{i}$ measures the log of the number of years since independence for country $i$ and $\log G D P 1960_{i}$ is the $\log$ of GDP of country $i$ in 1960 . We use OLS to estimate the above model and assume White heteroscedasticity robust standard errors in all specifications.

As reported in Table 2, state size - whether measured by geography or population size - and British colonization are the only variables that significantly explain nation-building variation across Africa. This finding is robust to all four models estimated here. The first finding adds credence to Herbst (2000)'s argument that the extension of state power has been a burden for African states and that post-colonial rulers with larger states have sought to overcome these inhibitions with more nation-building policies; the latter finding adds to the aforementioned literature on the effects of colonial regimes in the post-colonial era. Moreover, there is no relationship between ethno-linguisitic fractionalization and subsequent nation-building, suggesting that ethnicity has played less of a role in nation-building policies than was previously thought. Figure 1 plots nation-building policies and log of population size in 1960 for all 45 countries and reveals the strong positive relationship betwen the two variables.

\subsection{Nation-Building and Conflict}

We now test for the effect of nation-building policies on conflict in post-colonial Africa. We employ as our dependent variable Fearon \& Laitin (2003)'s panel data on civil war onset from 1945 to 1997, alongside an alternative dataset from PRIO. In all cases we use the ten control variables which

elsewhere for missing certain countries - such as Comoros and Equatorial Guinea - and relying too heavily upon linguistic definitions of ethnicity (Laitin and Posner, 2001). However, inasmuch as ethnicity should be considered potentially endogenous to nation-building, datasets from Alesina et al. (2003) and Fearon (2003) based on data from the 1990 s are not appropriate for use here.

${ }^{7}$ There are two countries in the dataset, namely Liberia and Mauritius, which have had zero nation-building policies since independence. Along with eight other countries they do not feature in our analysis due to missing data. 


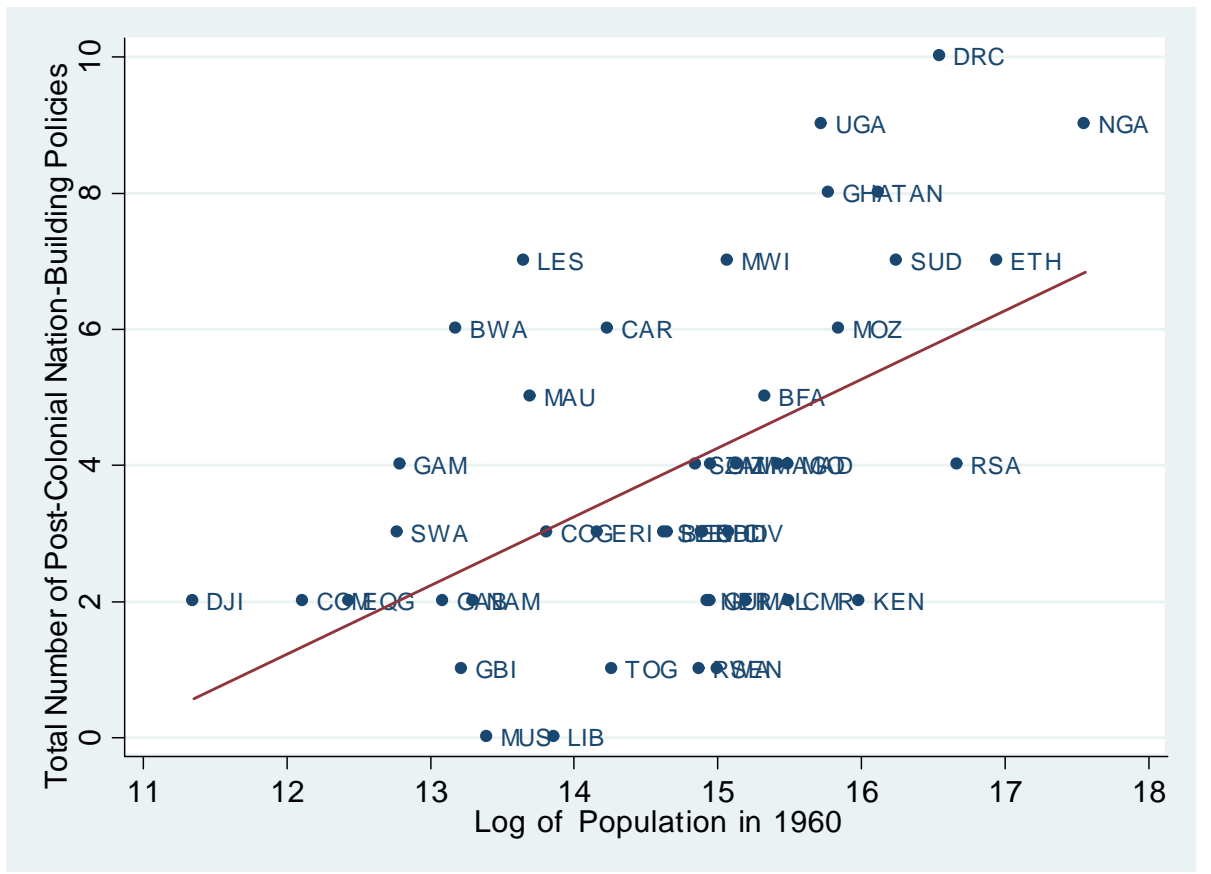

Figure 1: Total number of post-colonial nation-building policies against log of population in 1960.

Fearon \& Laitin (2003) found to be consistently associated with the onset of civil war, namely lagged (by one year) GDP, lagged log of population, the percentage of a given country considered mountainous, a dummy for noncontiguous states, a dummy for countries whose oil exports constituted more than $1 / 3$ of their export revenues, a dummy for political instability in the previous three years, lagged dummies for democracy (Polity IV score greater than 5, on a scale of -10 to 10 where 10 represents full democracy) and anocracy (Polity IV score between -5 and 5 ), and ethnic and religious fractionalization. We separate the set of nine variables where the year of implementation is coded as a 1 from the three variables (one-party states, land nationalization and conscription) where we assign a 1 to all years where the policy was in place.

To correct any potential problems due to reverse causality we took a closer look at the data to see if there were instances where policies and wars started in the same year. In the Fearon and Laitin dataset we found two such instances, namely Angola in 1975 and Sudan in 1983. In the Angolan case we decided to delete it as an example of civil war onset inasmuch as fighting between the FNLA, MPLA and UNITA began years before independence and cannot thus be said to have begun in 1975. In Sudan the abolition of the federal Southern Regional government took place in June 1983, a month before the founding of the rebel SPLA in exile under a platform which explicitly mentioned the South's federal powers as a casus belli (Johnson, 2003, pp. 62-64), assuring us that we have coded the data correctly. Inasmuch as the September laws which declared sharia law as state law in Sudan were implemented after the civil war had already began, we code it here as a policy from 1984 instead. 
We use logistic regressions to estimate the relationship between onset of civil war and nation building policies. The model we estimate is given by

$$
y_{i t}=\alpha+\beta X_{i t}+\mathbf{Z}_{i t} \gamma+\epsilon_{i t}
$$

where $y_{i t}$ represents the onset of civil war in country $i$ and time $t$, taking value 1 if the event occurs, and 0 otherwise. $X_{i t}$ is the nation building policy in country $i$ and time $t$, taking value 1 if the event occurs, and 0 otherwise. $\mathbf{Z}_{i t}$ is a vector of control variables for country $i$ and time $t . \epsilon_{i t}$ is an error term assumed to be normally distributed $N\left(0, \sigma_{\epsilon}^{2}\right)$.

We report our results in Table 3, with the two dependent variables listed in the first column of the table and the nine nation-building policies listed above each subsequent column. For the sake of simplicity we do not report the coefficients and standard errors for the ten aforementioned control variables. In the top panel of the table we present the results of the regressions with nation building policies measured in time period $t$. In the bottom panel we present the results of regressions using a more detailed definition of the impact of nation building policies over time. We allow the nation building policy variable $X_{i t}$ to take value 1 in both time $t$ and $t+1$, if the event occurs in time $t$, and 0 otherwise to to take into account of the fact that a nation building policy may have a lasting effect beyond the year of implementation. The number of observations for the Fearon and Laitin onset regressions is 1550 while for the PRIO onset regressions the number is 625 .

For some of the models we have run we encountered the problem of separation. This problem is commonly encountered by statisticians using binary response models; it occurs when the presence of one or more covariates explaining the model perfectly predict the outcome of interest, i.e., the dependent variable. In such cases the econometric software is typically unable to generate estimates of the parameters of interest because standard logistic regression generates infinite parameter estimates and standard errors. Firth (1993) proposes a solution, known as Penalized Likelihood Logistic Regression, by introducing a bias term into the standard likelihood function used to generate parameter estimates for logistic models (or any other generalised linear models). (See Zorn (2005) for details on this method.) Our estimates with a sub-script $F$ in Table 3 were generated using Firth's Penalized Likelihood Logistic Regression.

The results we obtain are striking: in contrast to what is predicted by the literature discussed in Section 1, we do not obtain a single instance where nation-building policies are negatively and significantly correlated with civil war onset. Instead we find that variables such as state name, currency, land, centralization and religion and language are significantly positively correlated with civil war onset across several specifications. However, these correlations are not robust across all models. ${ }^{8}$

\footnotetext{
${ }^{8}$ The coefficient for centralization using war onset data from PRIO does not differ across the two panels since there was only one such policy across the time span of the dataset, namely Sudan in 1983.
} 


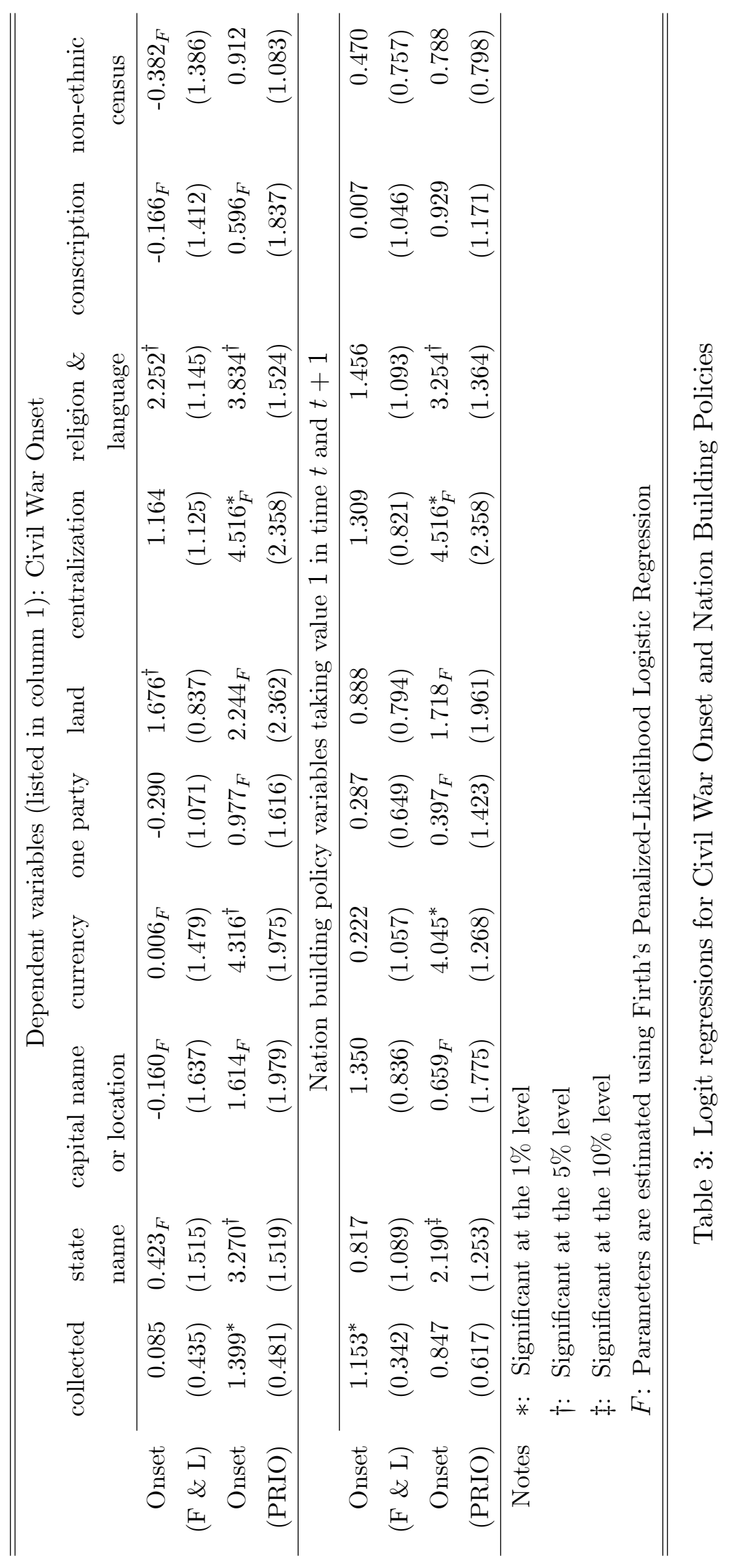




\begin{tabular}{rccc}
\hline \hline \multicolumn{4}{r}{ Dependent variables: Civil War Onset } \\
\cline { 2 - 4 } & one party & land & conscription \\
\hline Onset & 0.073 & 0.495 & -0.271 \\
$($ F \& L $)$ & $(0.457)$ & $(0.464)$ & $(0.454)$ \\
Onset & -0.841 & $1.588^{*}$ & -0.151 \\
(PRIO) & $(0.734)$ & $(0.614)$ & $(0.561)$ \\
\hline Notes & $*$ : & Significant at the $1 \%$ level \\
& $\dagger:$ & Significant at the $5 \%$ level \\
& $\ddagger$ : & Significant at the $10 \%$ level \\
\hline \hline
\end{tabular}

Table 4: Logit regressions for Civil War Onset and Nation Building Policies, using second definition of Nation Building Policy

In Table 4 we report the results from regressions which use the second definition of the nation building policies, described in Section 3.1. While none of the three variables are consistently correlated with civil war onset, we do however obtain a significant positive association for land nationalisation when using the PRIO definition of civil war onset.

\section{Interpretation}

These results may appear odd at first. Yet the lack of any negative significant relationship between nation-building policies and civil war onset as well as the occasional positive relationship can be explained by the fact that many of these nation-building policies were merely seen as a smokescreen to advance the interests of the President and his party. For instance, Kwame Nkrumah's attempt at conscripting Ghanian youth into his Young Pioneer Movement quickly degenerated into an indoctrination of Nkrumahism with a resort to "ritualistic pledges of loyalty to Nkrumah" (Smock, 1976, p. 133), while leaders were recruited on the basis of party loyalty rather than ability.

Perhaps most importantly, however, in many instances nation-building policies were highly controversial and led to more conflict than integration. For instance, in Nigeria the 1979 and 1983 presidential candidate Obafemi Awolowo claimed that, if elected, "he would hire the American Walt Disney Corporation to convert the new site [at Abuja] into an amusement park," in large part because his constituency in Lagos and the south-west stood to lose out on the move (Moore, 1984, p. 173). In Côte d'Ivoire and Malawi the new capitals happened to be either in or very close to the president's home town, which meant that subsequent capital city development - including the construction of the world's largest church in Yamoussoukro, Côte d'Ivoire - was viewed as ethnically biased (Potts, 1985). As regards language policy, while President Idi Amin of Uganda declared Swahili as the national language in 1973, the language became synonymous with his murderous regime and the language was eventually scrapped as a national language in the 1995 constitution. Similarly, Hailie 
Selassie's efforts to promote Amharic and Orthodox Christianity only drew ire from ethnic minorities in Ethiopia; as a result Meles Zenawi's regime more recently created an ethno-federal system allowing for a multitude of languages and religions. Finally, land nationalization in the 1970s in both the DRC and Sudan allowed migrants to acquire land outside their traditional regions; in Darfur and the eastern DRC this policy lead to increasing land inequalities as locals saw their land increasingly occupied by migrants, eventually contributing to the outbreak of violent "sons of the soil" conflict and civil war in both locations (Green, 2010).

These failed cases of nation-building thereby put Tanzania's more successful experience into question. In contrast to Miguel (2004) and others who suggest that Tanzania should be a model example of nation-building within Africa, the evidence here suggests that Tanzanian nation-building policies may not have been particularly helpful in the formation of a Tanzanian national identity. Indeed, there were eight distinct examples of nation-building policies in post-colonial Tanzania, or one more than Ethiopia or Sudan and one less than Nigeria and Uganda, all of whom have had far more conflictual political experiences than Tanzania. Why was moving the national capital from a coastal city towards one more centrally located less controversial in Tanzania than in Nigeria, and why was land nationalization so much more divisive in the Sudan and Uganda than in Tanzania? And why did the promotion of Swahili in Tanzania have such a radically different outcome than the promotion of Amharic in Ethiopia or Swahili in Uganda? The obvious answer is that the nationbuilding policies themselves were not responsible for their subsequent success or failure at promoting national integration, but that deeper structural reasons such as a lack of inter-regional inequalities in Tanzania have been more responsible for its exceptional stability than any one particular set of policies (Green, 2011).

\section{Conclusion}

In this paper we developed a new dataset of nine distinct types of nation-building policies in postcolonial Africa. We showed how state size and British colonialism were correlated with higher numbers of post-colonial nation-building policies. We also showed there was no evidence of a negative relationship between the incidence of nation building policies and the onset of civil war. In other words, we find no evidence that the implementation of nation-building policies is associated with a reduction in the onset of civil wars. As such this paper adds to other evidence that nation-building policies do not promote political stability and may in some cases even promote instability, as for instance in the positive correlation betwen higher levels of education and ethnic violence (Lange and Dawson, 2010). More generally, however, it suggests that nation-building should not be seen as a panacea for African conflicts and that copying Tanzania is not a recipe for success. In other words, promoting political stability in Africa is a long and difficult process and is not one that can be easily achieved through select policies. 
Future work may wish to investigate additional nation-building policies focussed on culture, education and sports, among others. Additional work could also investigate these relationships at a more micro-level, both quantitatively and ethnographically. Indeed, recent experimental studies of the relationship between national symbols and national identity has produced equivocal results: in a series of experiments in Israel Hassin et al. (2007) found that that subliminal exposure to the Israeli national flag has a moderating affect on subjects' identification with Israeli nationalism, while in the United States Kemmelmeier and Winter (2008) found that exposure to the American flag increased feelings of superiority over other countries but did not increase patriotic feelings of love for the US. Finally, similar work could examine other parts of the post-colonial world, such as Latin America in the 19th century, to see if these relationships differ across time and space.

\section{References}

[1] Alesina, A., Devleeshauwer, A., Easterly, W., Kurlat, S., \& Wacziarg, R. (2003). Fractionalization. Journal of Economic Growth, 8(2), 155-194.

[2] Anderson, B. (1991). Imagined Communities: Reflections on the Origins and Spread of Nationalism. London: Verso.

[3] Barnes, B. (1982). Education for Socialism in Mozambique. Comparative Education Review, $26(3), 406-419$.

[4] Bayart, J. F. (1973). One-Party Government and Political Development in Cameroon. African Affairs, 72(287), 125-144.

[5] Billig, M. (1995). Banal Nationalism. London: Sage.

[6] Binder, L. (1964). National Integration and Political Development. American Political Science Review, 58(3), 622-631

[7] Blanton, R., Mason, T. D., \& Athow, B. (2001). Colonial Style and Post-Colonial Ethnic Conflict in Africa. Journal of Peace Research, 38(4), 473-492.

[8] Bruce, J. W. (1998). Country Profiles of Land Tenure: Africa, 1996. Research Paper \#130, Land Tenure Center, University of Wisconsin, Madison.

[9] Chan, S. (1992). Kaunda and Southern Africa: Image and Reality in Foreign Policy. London: IB Tauris.

[10] Chazan, N. (1982). Ethnicity and Politics in Ghana. Political Science Quarterly, 97(3), 461-485. 
[11] Coleman, J. S., \& Rosberg, C. G. (Eds.). (1966). Political Parties and National Integration in Tropical Africa. Berkeley, CA: University of California Press.

[12] Collier, P. (2009). Wars, Guns and Votes: Democracy in Dangerous Places. New York: Harper.

[13] Dunn, K. C. (2001). Imagining Mobutu's Zaïre: The Production and Consumption of Identity in International Relations. Millennium - Journal of International Studies, 30(2), 235-258.

[14] Englebert, P., Tarango, S., \& Carter, M. (2002). Dismemberment and Suffocation: A Contribution to the Debate on African Boundaries. Comparative Political Studies, 35(10), 1093-1118.

[15] Fearon, J. D. (2003). Ethnic and Cultural Diversity by Country. Journal of Economic Growth, $8(2), 195-222$.

[16] Fearon, J. D., \& Laitin, D. D. (2003). Ethnicity, Insurgency, and Civil War. American Political Science Review, $97(1)$, 75-90.

[17] Firth, D. (1993). Bias Reduction of Maximum Likelihood Estimate. Biometrika, 80(1), 27-38.

[18] Francis, P. (1984). 'For the Use and Common Benefit of All Nigerians': Consequences of the 1978 Land Nationalization. Africa: Journal of the International African Institute, 54(3), 5-28.

[19] Gennaioli, N., \& Rainer, I. (2007). The Modern Impact of Precolonial Centralization in Africa. Journal of Economic Growth, 12(3), 185-234.

[20] Gray, R. (1982). "Khalai-Khalai": People's History in Mozambique. History Workshop Journal, $14,143-152$.

[21] Green, E. D. (2010). The Political Demography of Conflict in Modern Africa. DESTIN Working Paper \#111, Development Studies Institute, London School of Economics.

[22] Green, E. D. (2011). The Political Economy of Nation Formation in Modern Tanzania: Explaining Stability in the Face of Diversity. Commonwealth and Comparative Politics, 49(2), 223-244.

[23] Harber, C. (1989). Politics in African Education. London: Macmillan.

[24] Hassin, R. R., Ferguson, M. L., Shidlovski, D., \& Gross, T. (2007). Subliminal Exposure to National Flags Affects Political Thought and Behavior. Proceedings of the National Academy of Sciences of the United States of America, 104(50), 19757-19761.

[25] Helleiner, E. (1998). National Currencies and National Identities. American Behavioral Scientist, $41(10), 1409-1436$.

[26] Herbst, J. (2000). States and Power in Africa: Comparative Lessons in Authority and Control. Princeton, NJ: Princeton University Press. 
[27] Heston, A., Summers, R., \& Aten, B. (2009). Penn World Table, Version 6.3, Center for International Comparisons of Production, Income and Prices at the University of Pennsylvania.

[28] Johnson, D. H. (2003). The Root Causes of Sudan's Civil Wars. Oxford: James Currey.

[29] Kasanga, K., \& Kotey, N. A. (2001). Land Management in Ghana: Building on Tradition and Modernity. International Institute for Environment and Development, London.

[30] Kemmelmeier, M. \& Winter, D. G. (2008). Sowing Patriotism, But Reaping Nationalism? Consequences of Exposure to the American Flag. Political Psychology, 29(8), 859-879.

[31] Kevane, M. (2005). Nation-building, multi-culturalism, and civil conflict in Africa: An analysis of imagery on postage stamps. Mimeo, Department of Economics, Santa Clara University.

[32] Kevane, M. (2008). Official Representations of the Nation: Comparating the Postage Stamps of Sudan and Burkina Faso. African Studies Quarterly, 10(1), 71-94.

[33] Kibreab, G. (2009). Forced Labour in Eritrea. Journal of Modern African Studies, 47(1), 41-72.

[34] Laitin, D. D. (2007). Nations, States and Violence. Oxford: Oxford University Press.

[35] Laitin, D. D., \& Posner, D. N. (2001). The Implications of Constructivism for Constructing Ethnic Fractionalization Indices. APSA-CP: The Comparative Politics Newsletter, 12, 13-17.

[36] Lange, M., \& Dawson, A. (2010). Education and Ethnic Violence: A Cross-National Time-Series Analysis. Nationalism and Ethnic Politics, 16(2), 216-239.

[37] Lieberman, E. S., \& Singh, P. (2009). Measuring State Institutionalization of Ethnic Categories across Time and Space. Newsletter of the American Political Science Association Organized Section for Qualitative and Multi-Method Research, 7(1), 29-35.

[38] Mamdani, M. (1996). Citizen and Subject: Contemporary Africa and the Legacy of Late Colonialism. Princeton, N.J: Princeton University Press.

[39] Markakis, J., \& Beyene, A. (1967). Representative Institutions in Ethiopia. Journal of Modern African Studies, 5(2), 193-219.

[40] Marten, L., \& Kula, N. C. (2008). Zambia: 'One Zambia, One Nation, Many Languages'. In A. Simpson (Ed.), Language and National Identity in Africa (pp. 291-313). Oxford: Oxford University Press.

[41] Miguel, E. (2004). Tribe or Nation? Nation Building and Public Goods in Kenya versus Tanzania. World Politics, 56(3), 327-362. 
[42] Miguel, E., Satyanath, S., \& Sergenti, E. (2004). Economic Shocks and Civil Conflict: An Instrumental Variables Approach. Journal of Political Economy, 112(4), 725-753.

[43] Moore, J. (1984). The Political History of Nigeria's New Capital. Journal of Modern African Studies, 22(1), 167-175.

[44] Morning, A. (2008). Ethnic Classification in Global Perspective: A Cross-National Survey of the 2000 Census Round. Population Research and Policy Review, 27(2), 239-272.

[45] Potts, D. (1985). Capital Relocation in Africa: The Case of Lilongwe in Malawi. Geographical Journal, $151(2), 182-196$.

[46] Przeworski, A. (2009). Self-Government in Our Times. Annual Review of Political Science, 12, 71-92.

[47] Roeder, P. (2001).Ethnolinguistic Fractionalization (ELF) Indices, 1961 and 1985. http://weber.ucsd.edu/ ${ }^{\sim}$ proeder/elf.htm.

[48] Sanborn, J. (2002). Drafing the Russian Nation: Military Conscription, Total War and Mass Politics, 1905-1925. DeKalb, IL: Northern Illinois University Press.

[49] Santschi, M. (2008). Counting 'New Sudan'. African Affairs, 107(429), 631-640.

[50] Schiffrin, H. (1957). Sun Yat-sen's Early Land Policy: The Origin and Meaning of "Equalization of Land Rights." Journal of Asian Studies, 16(4), 549-564.

[51] Smith, L. (2008). The Politics of Contemporary Language Policy in Ethiopia. Journal of Developing Societies, $24(2), 207-243$.

[52] Smock, A. C. (1976). Education and National Integration in Ghana. In D. R. Smock \& K. Bentsi-Enchill (Eds.), The Search for National Integration in Africa (pp. 117-138). New York: Free Press.

[53] Tronvoll, K. (1998). The Process of Nation-Building in Post-War Eritrea: Created from Below or Directed from Above? Journal of Modern African Studies, 36(3), 461-482.

[54] United Nations. (2008). World Urbanization Prospects: The 2007 Revision. Department of Economic and Social Affairs/Population Division.

[55] Weber, E. J. (1976). Peasants into Frenchmen: The Modernization of Rural France, 1870-1914. Stanford, CA: Stanford University Press.

[56] Young, M. C. (1976). The Politics of Cultural Pluralism. Madison, WI: University of Wisconsin Press. 
[57] Young, M. C. (2004). Revisiting Nationalism and Ethnicity in Africa. Los Angeles: University of California, Los Angeles.

[58] Zolberg, A. R. (1967). Patterns of National Integration. Journal of Modern African Studies, $5(4), 449-467$.

[59] Zorn, C. (2005). A Solution to Separation in Binary Response Models. Political Analysis, 13(2), 157-170.

\section{A Data Sources}

British: Dummy equals 1 if a state was ever colonized by the UK $(\mathrm{n}=18)$ and 0 otherwise.

Civil War Onset: Onset of a civil war in a given year. Sources: Fearon \& Laitin (2003), Miguel et al. (2004).

Pre-Colonial Centralization: The percentage of a country's pre-colonial population which consisted of ethnic groups living under a centralized political system, based on anthropological data from the Ethnographic Atlas (1967) and ethnic diversity data from the Soviet Atlas Narodov Mira (1964). Source: Gennaioli \& Rainer (2007).

ELF: Ethnolinguistic fractionalization per country in 1961. Source: Roeder (2001).

Log GDP/1960: Natural log of GDP/capita in 1960. Source: Heston, Summers, \& Aten (2009).

Portuguese: Dummy equals 1 if a state was ever colonized by Portugal $(n=3)$ and 0 otherwise.

Log Years since Independence: Log of the number of years since independence from colonial rule. In the case of Ethiopia we assign the date 1896 as that was when the Ethiopian state was de facto recognized as independent by European powers; for Liberia and South Africa we assign the dates 1847 and 1910, respectively.

\section{B Countries in dataset}




\begin{tabular}{lll}
\hline \hline Angola & Ethiopia & Namibia \\
Benin & Gabon & Niger \\
Botswana & Gambia & Nigeria \\
Burkina & Ghana & Rwanda \\
Burundi & Guinea & Senegal \\
Cameroon & Guinea-Bissau & Sierra Leone \\
Central African Republic & Kenya & Somalia \\
Chad & Lesotho & South Africa \\
Comoros & Liberia & Sudan \\
Congo, DR/Zaire & Madagascar & Swaziland \\
Congo, Republic of & Malawi & Tanzania \\
Côte d'Ivoire & Mali & Togo \\
Djibouti & Mauritania & Uganda \\
Equatorial Guinea & Mauritius & Zambia \\
Eritrea & Mozambique & Zimbabwe \\
\hline \hline
\end{tabular}

Table 5: Countries included in analysis 